\title{
Um olhar sobre a obra Ditos e malditos: desejos de uma clausura
}

\author{
Inês Alcaraz Marocco' ${ }^{1}$
}

\section{Resumo}

Trata-se de um depoimento sobre alguns aspectos performáticos da atuação de bailarinos/intérpretes do espetáculo Ditos e malditos: desejos de uma clausura.

Palavras-chave: Depoimento-Espetáculo-Atuação-Performance-Dança /Teatro-Teatro pós-dramático

\section{A look on the work Ditos e malditos: desejos de uma clausura \\ Abstract}

This is a testimony about some performatic aspects of the acting of dancers/interpreters of the play Ditos e malditos: desejos de uma clausura.

Keywords: Testimony - Play - Acting - Performance - Dance/Theater- post-dramatic theater

Não ao espetáculo, não ao virtuosismo, não às transformações e à magia e à simulação, não ao glamour e à transcendência da imagem de estrela, não ao heróico não ao anti-heróico não ao imaginário do lixo não ao envolvimento do performer ou do espectador não ao estilo não ao artificialismo intencional não à sedução do espectador pela astúcia do performer não à excentricidade não à comoção ou ao deixar-se comover (Manifesto da renúncia de Yvonne Rainer apud GOLDBERG, 2006, p. 131)

Da mesma forma que, em 1965, quando o Manifesto da renúncia foi escrito por Yvonne Rainer - coreógrafa que fez parte do Judson Dance Theater, em Nova York -, época de grandes mudanças de paradigmas, em que a arte também reivindicava o seu valor intrínseco em reação à narrativa, ao academicismo, ao drama, realçando seus aspectos formais e funcionais, nos anos 1980, na Europa, vemos que esses mesmos valores retornam com a mesma força. O que nos anos 1960 representava a rebeldia e vinha em contraposição ao estabelecido, nos anos 1980, as companhias e grupos de dança recebem apoio da união para desenvolver suas pesquisas com os mesmos objetivos.

\footnotetext{
1 Doutora em Esthétique Sciences et Technologie des Arts option Études Théâtrales et Chorégraphiques à I'Université de Paris 8 Saint-Denis, em Paris. Formação no Curso de Mime-Théâtre et Mouvement, na École International Jacques Lecoq, em Paris. Pesquisadora, diretora teatral e professora do Departamento de Arte Dramática da Universidade Federal do Rio Grande do Sul ( UFRGS), em Porto Alegre.
} 
Nos anos 1980, mais especificamente no período de 1981 a 1985, assistimos a vários grupos de dança contemporânea em Paris, no período em que cursávamos o Mestrado. Nesta época, conhecemos muitas companhias francesas, como a de Maguy Marin, Jean Claude Gallotta, ${ }^{2}$ além das alemãs Pina Bausch e Susanne Link, a belga Anne Teresa de Keersmarker, o holandês Jiri Kylian do Nederlands dans Theater e a norte-americana Carolyn Carlson, entre outros. Alguns deles são conhecidos e reconhecidos pela excelência de seus trabalhos até hoje.

Revendo os programas ${ }^{3}$ dos espetáculos destas companhias, relembramos, pelas fotos, as criações que nos impressionaram e que até hoje guardamos na memória. As críticas da época apontavam o quanto esses coreógrafos foram inovadores nas suas criações e destacavam os verdadeiros espetáculos que aconteciam, a sua teatralidade e a característica híbrida das coreografias, ao mesclarem diferentes áreas das artes como o teatro, a literatura, o cinema e o vídeo, além de misturarem em cena atores e dançarinos. Na realidade, o que víamos era o desenvolvimento de espetáculos de teatro-dança.

Esses espetáculos evidenciavam uma pesquisa de linguagem desenvolvida à exaustão por esses novos artistas. Isso só foi possível graças às subvenções à cultura concedidas pelo governo francês da época (anos 1980), encabeçadas por Jack Lang, ${ }^{4}$ principalmente às pesquisas no campo da dança que era uma área emergente. Para nós, eram fascinantes as inúmeras possibilidades cênicas de atuação e de utilização do espaço, qualidades que não encontrávamos no teatro.

Hoje, 30 anos depois, as fronteiras entre essas duas áreas artísticas, o teatro e a dança, são cada vez mais tênues. O teatro e as outras artes em geral já não podem ser mais facilmente identificados como pertencentes a uma única linha. Suas fronteiras tornaram-se cada vez mais fluídas, fragéis, e essa condição, ao mesmo tempo em que as favorece, possibilita mal-entendidos. O que nos anos 1980 parecia inovador, a dança-teatro, hoje, já não atende mais às expressões artísticas que surgem a cada dia. Entre as diferentes denominações, cito as mais recorrentes hoje, como as artes da performance, a arte experimental, o teatro pós-dramático, entre outros. Esse espaço aparentemente sem regras e limites, onde quase tudo pode ser, tem possibilitado o surgimento de muitos equívocos em nome da arte. E, no Brasil, mais especificamente

\footnotetext{
${ }^{2}$ Outras companhias atuantes na época foram as de Régine Chopinot, François Verret, Dominique Bagouet, Emile Dubois e a norte-americana Karole Armitage.

${ }^{3}$ Programas do Théâtre de la Ville 1984/85, 17ème saison. Journal n. 65, août 84.

${ }^{4}$ Jack Lang foi ministro da cultura na França, durante o governo de François Mitterrand, no período de 1981 a 1995.
} 
em Porto Alegre, constatamos que são poucas as companhias a investir neste tipo de criação artística que não se enquadra em uma única linha .É importante colocar que, entre os profissionais que optaram por essa via e verticalizam os seus conhecimentos e prática artística neste sentido, está a coreógrafa Carlota Albuquerque. O próprio nome do grupo que dirige - Terpsí Teatro de Dança - anuncia esta opção.

Na última criação do grupo, intitulada Ditos e malditos: desejos da clausura, ${ }^{5}$ os bailarinos/intérpretes, como são denominados por Carlota Albuquerque, navegam entre diferentes universos: da dança, do teatro contemporâneo, do vídeo, do cinema, da literatura e de seus próprios desejos, em um espaço/instalação modulável, transformável por cada um. E, por contemplar diferentes áreas artísticas, miscigenadas, interpostas, coladas em uma espécie de montagem, o trabalho de Carlota aproxima-se bastante das características da disciplina da Performance Art, como podemos perceber através da conceituação de Goldberg (2006, p. IX), para quem

\section{[...] qualquer definição mais exata negaria de imediato a própria possibilidade da performance, pois seus praticantes usam livremente quaisquer disciplinas e quaisquer meios como material - literatura, poesia, teatro, música, dança, arquitetura e pintura, assim como o vídeo, cinema, slides e narrações -, empregando-os nas mais diversas combinações. De fato, nenhuma outra forma de expressão artística tem um programa tão ilimitado, uma vez que cada performer cria sua própria definição ao longo de seu processo e modo de execução.}

Na realidade, a disciplina da Performance Arts é bastante complexa, abrangendo inclusive o teatro-dança. Para a docente da New York University (NYU) e curadora de vários projetos internacionais na área da performance, RoseLee Goldberg, o teatro-dança é classificado como um dos vieses da performance, dedicando um capítulo para essa linha, no seu livro $A$ arte da performance: do futurismo ao presente (Cf. 2006, p. 192-197). Nessa mesma perspectiva, encontramos características semeIhantes na área da Performance Arts, no campo do teatro, mais especificamente no teatro pós-dramático, conforme define Lehmann (2007, p. 91-92):

\footnotetext{
O teatro já não aspira à totalidade de uma composição estética feita de palavra, sentido, som, gesto etc., que se oferece à percepção como construção integral; antes, assume seu caráter de fragmento e de parcialidade. Ele abdica do critério da unidade e da síntese, há tanto tempo incontestável, e se dispõe à oportunidade (ou ao perigo) de confiar em estímulos isolados, pedaços e microestruturas de textos para se tornar um novo tipo de prática. Desse modo, ele descobre uma inovada presença do performer a partir de uma mutação do actor e estabelece a paisagem teatral multiforme, para além das formas centralizadas do drama.
}

\footnotetext{
${ }^{5}$ Este espetáculo é uma criação da companhia Terpsí Teatro de Dança, sob a direção de Carlota Albuquerque, que estreou em 2008. Eu o assisti na temporada de 2011.
} 
Com essas definições da Performance Art (Goldberg) e do teatro pós-dramático (Lehman), percebemos que existem muitos pontos em comum entre essas duas vertentes conceituais. E que, com o apoio delas, podemos nos aproximar mais do trabalho realizado por Carlota, que poderia ser considerado como um espetáculo performático, pois, como já citado acima, o espetáculo se compõe de vários aspectos de diferentes campos das artes, entre outras coisas. E, da mesma forma que as duas vertentes citadas, o espetáculo Ditos e malditos: desejos de uma clausura caracteriza-se pelo viés experimental e provocador. Goldberg (2006, p. 217) conclui o seu livro com a frase: "a arte da performance continua a desafiar as definições e se mantém tão imprevisível e provocadora como sempre foi." Para Lehman (2007, p. 37), "o teatro pós-dramático é essencialmente (mas não exclusivamente) ligado ao campo teatral experimental e disposto a correr riscos artísticos".

Tendo em vista a complexidade de que se constitui o espetáculo, faremos uma breve reflexão sobre algumas características performativas dos trabalhos relacionados, aliando-as à atuação dos bailarinos/intérpretes e à sua ingerência no espaço de jogo, não só porque têm relação direta com a nossa área de trabalho - o teatro -, mas também porque intuímos que o seu papel é fundamental na realização deste espetáculo. Para efetivar esse trabalho, apontaremos alguns momentos da montagem em que se pode detectar esses aspectos .

O espetáculo inicia de forma bastante teatral e provocadora, com um bailarino/ intérprete sentado num vaso sanitário no alto da plateia do espaço do Museu do Trabalho, ${ }^{6}$ dizendo um texto da peça teatral Ubu rei, ${ }^{7}$ de Alfred Jarry. Esta forma de começar o espetáculo, ocupando outro espaço que não o palco, junto com o público na plateia, e ainda sentado num vaso sanitário é bastante sintomática como característica de um espetáculo diferente, fora dos padrões convencionais. Além disso, a peça de Jarry é considerada por Goldberg (2006) como a primeira obra de vanguarda e performática na área do teatro. $E$ também porque abrir o espetáculo dessa forma é apresentar o seu tom performático. É pertinente a posição do bailarino/intérprete sentado no vaso de onde sai um foco de luz, pois a primeira palavra que o personagem Ubu

\footnotetext{
${ }^{6}$ A companhia Terpsí está realizando uma residência artística na casa de espetáculos Museu do Trabalho, da Prefeitura da cidade de Porto Alegre.

${ }^{7}$ Peça teatral escrita, em 1890, pelo autor francês Alfred Jarry, quando ele tinha 15 anos: "peça bufa precursora do teatro do absurdo, farsa condimentada de humor contundente e feroz, sátira delirante que chega ao surrealismo e até o ultrapassa, paródia aloprada de textos grandiloqüentes, denúnica caricatural das imposturas burguesas, espetáculo raro de fantasia e sarcasmo" (Mariano Torres in JARRY, 1972)
} 
diz no texto é merdra, o que causou nos meios artísticos e literários da época, final do século XIX, uma grande revolução. Mas o que é interessante pontuar é que, mesmo dizendo fragmentos de um texto teatral, o bailarino/intérprete não representa o personagem Ubu. Não temos aqui uma representação, e sim uma presentação (LÉPINOIS, 2001, p. 38). "Para a performance, assim como para o teatro pós-dramático, o que está em primeiro plano não é a encarnação de um personagem, mas a vividez, a presença provocante do homem" (LEHMANN, 2007, p. 225). Além disso, tanto o happening como a arte performática e o teatro pós-dramático caracterizam-se pela perda de significado do texto, com sua devida coerência literária, o que acaba por reforçar a atuação do ator: "ambas acentuam a presença (o fazer no real) em detrimento da representação (a mimese do fictício), o ato em detrimento da totalidade" (LEHMANN, 2007, p. 170). Prioriza-se o aqui/agora da presença carnal do ator/performer, a comunicação palco/ plateia dá-se por outras vias que não a do racional.

É importante ressaltar que, quando falamos na questão da presença física do ator/bailarino, a primeira imagem que vem é a de um corpo diferente, extraordinário. $\mathrm{Na}$ realidade, como os atores/dançarinos de Pina Bausch, o grupo Terpsí é composto por bailarinos, homens e mulheres com corpos comuns, diferentes do corpo ideal da bailarina clássica, por exemplo.

Evidentemente que os componentes do grupo Terpsí possuem corpos treinados e codificados pela arte da dança, o que Ihes possibilita possuir uma presença física a priori. Mas isso é reforçado no trabalho proposto pela coreógrafa, ao criar o espetáculo. Sem a preocupação de conceber personagens, cada bailarino/intérprete merguIhou nas situações propostas, buscando situar a si mesmo neste universo ficcional, de forma a mais transparente possível, sem máscaras. Esse tipo de procedimento durante o processo de criação é visível no espetáculo, da mesma maneira que na criação teatral, quando se trabalha com as individualidades de cada artista, assim como a utilização do espaço enquanto instaurador do jogo.

Relativo ainda à atuação do bailarino/intérprete, temos a questão do texto, da palavra. Do que se fala e de como se diz o texto, ou as narrativas. Como no teatro contemporâneo, neste espetáculo não existe uma dramaturgia linear, com início, meio e fim, e sim o que poderíamos denominar de escritura fragmentada (Cf. RYNGAERT, 1998, p. 226-227), que também encontramos nas artes da performance com outra denominação, narrativa enviesada (Cf. KANTON, 2009, p. 15). Os fragmentos de textos 
ou os ditos populares são pronunciados sem nenhuma intenção prévia que nos situe em alguma situação dramática. O objetivo é dizer o texto naquele contexto de espetáculo. Da mesma forma que no teatro pós-dramático, no happening e na arte performática, com a perda do significado do texto e da sua coerência literária, são produzidos acontecimentos: "Neste teatro pós-dramático do acontecimento há uma efetivação de atos que se realizam no aqui e agora e que têm sua recompensa no momento em que acontecem, sem precisar deixar quaisquer vestígios duradouros do sentido, do monumento cultural etc (LEHMANN, 2007, p. 169-170).

Em vários momentos do espetáculo, o nosso olhar é dirigido para o centro da cena, por uma bailarina /intérprete que, de costas para o público, abre as duas portas de correr que fazem parte do cenário, possibilitando-nos a visão de diferentes acontecimentos. Como num espaço pós-dramático (LEHMANN, 2007, p. 274), "o espaço da representação é redefinido no decorrer da encenação", somos conduzidos pela bailarina/intérprete para um local composto de diferentes campos que se alternam, pontuados pela luz e por objetos. Da mesma forma que na pintura e no cinema, nosso olhar é conduzido/direcionado pela bailarina/intérprete, ao abrir a porta de diferentes maneiras, com larguras que variam de tamanho durante todo o espetáculo, como uma espécie de zoom, ampliando ou afinando nosso olhar, descortinando diversas surpresas. Em outros momentos, os próprios bailarinos/intérpretes dirigem os focos da cena, iluminando eles mesmos, com lanternas, os momentos a serem vistos. Aqui, o grupo brinca com a linguagem do cinema, algumas situações, inclusive, possuem um fundo musical cinematográfico, hollywoodiano. Além disso, pela sua riqueza de imagens, diríamos que o espetáculo também se insere na categoria de dramaturgia da imagem (SANCHEZ, 1994, p. 131):

\footnotetext{
La trama construída por el poeta puede en ocasiones servir de eje ordenador. Pero también se puede confira la ordenación a la propuesta plástica,a la musical, a la actoral, o incluso al discurso subjectivo del creador escénico.O bien puede aspirarse a eliminar la preponderancia de uno de los discursos ,multiplicar las interrupciones, las mediaciones,las superposiciones, y convertir la escena en campo de interacciones, en cuyo interior la actividad dramaturgica se concibe como fijación de un frágil equilíbrio.
}

Além disso, nesses tipos de dramaturgia não existem personagens com biografias, o que propicia a existência de figuras como a bailarina/intérprete que, em um determinado momento do espetáculo, se metamorfoseia em diversas formas de seres vivos, como animais e humanos, com os seus movimentos. Ela utiliza-se de serrotes como extensões de seus braços, e desloca-se no espaço realizando movimentos rápidos e difíceis, arriscados que nos prendem a atenção pelo perigo eminente que 
representam, pois a bailarina/intérprete pode se machucar. Outra figura se desenha no final do espetáculo com os mesmos acessórios - os serrotes -, quando outra bailarina/intérprete utiliza-se deles ainda como extensão dos braços. Mas, desta vez, para formar o desenho de asas no espaço. A imagem final que fica do espetáculo é essa figura de um ser alado em equilíbrio delicado sobre um móvel que lembra pelo seu formato uma cadeira de balanço.

À guisa de conclusão, ao mesmo tempo em que a arte da performance reflete a irrupção dos meios interativos e os novos modos de percepção abertos pelo avanço da realidade virtual da indústria de comunicações, ela também é um antídoto essencial provocado pela tecnologia. A escolha do aspecto de atuação do bailarino/intérprete na obra Ditos e malditos: desejos de uma clausura para tecer algumas reflexões vem reforçar a importância da necessidade cada vez maior da presença do artista performático em tempo real, da "suspensão do tempo" do performer ao vivo que confere a esse meio de expressão sua posição central.

Nestes tempos de limites e fronteiras cada vez mais rarefeitas, ${ }^{8}$ em que a sutileza e o mistério são frequentemente menos presentes no nosso cotidiano, a arte tem um papel, progressivamente, mais importante, como o de nos despertar para aquilo que não enxergamos mais. A contribuição de Carlota e de seu grupo Terpsí, neste sentido, é fundamental para a criação de uma arte que seja transcendente e transformadora.

\section{Referências}

GOLDBERG, Roselee. A arte da performance. Do futurismo ao presente. São Paulo: Martins Fontes, 2006.

JARRY, Alfred. Ubu rei. Rio de Janeiro: Civilização Brasileira, 1972.

KANTON, Katia. Narrativas enviesadas. In: TEMAS da Arte Contemporânea. São Paulo: Martins Fontes, 2009.

LEHMANN,Hans-Thies. Teatro pós-dramático. Apresentação Sérgio de Carvalho. Trad. Pedro Süssekind. São Paulo: Cosac Naify, 2007.

LÉPINOIS, Gérard. Présentation? Représentation? Théâtre Public, Paris, n. 157, jan/fév. 2001. RYNGAERT, Jean-Pierre. Ler o teatro contemporâneo. São Paulo: Martins Fontes, 1998.

SANCHEZ, José A. Dramaturgias de la imagen. Murcia/Cuenca: Servicio de Publicaciones de la Universidade de Castilla-La Mancha, 1994.

SCHECHNER, Richard. Teoria da performance. In: Essays on performance theory. New York: Drama Book Specialists, 1977.

8 Sobre essa expressão, ver artigo de Maria Beatriz de Medeiros, Bordas rarefeitas da linguagem artística da performance, In: TEIXEIRA, João Gabriel Lima Cruz (Org.). Performance, cultura e espetacularidade. Brasília: UnB, 2001. 